\title{
EFEKTIVITAS OTONOMI DAERAH DALAM MEMBANGUN PEMBERDAYAAN SUMBER DAYA MANUSIA PADA MASYARAKAT PEDESAAN
}

\author{
Kantirina Rachaju \\ Prodi Ilmu Pemerintahan, Sekolah Tinggi Ilmu Sosial dan Ilmu Politik, Widyapuri Mandiri \\ E-mail:kantirina@gmail.com
}

\begin{abstract}
ABSTRAK. Reformasi 1998 sebagai dasar pijakan untuk meninjau ulang kembali tatanan otonomi daerah baru dalam mewujudkan good governance (kepemerintahan yang baik), hakikatnya mereformasi landasan kehidupan bermasyarakat, berbangsa dan bernegara yang sentralistik, yaitu: (1) Amandemen Undang-undang Dasar Republik Indonesia 1945; (2) Reformasi birokrasi Pemerintah/ Penyelenggara Negara, dan (3) Reformasi (membangun) Sumber Daya Manusia (masyarakat pedesaan). Dalam mewujudkan good governance sehingga sesuai dengan isi sila kelima dari ideologi Pancasila dan Pembukaan Undang-undang Dasar Republik Indonesia 1945, yaitu mencerdaskan kehidupan bangsa dan memajukan kesejahteraan umum. Dalam proses pelaksaanan penyelenggaraan pemerintahan yang sentralisasi masih banyak ditemukannya berbagai macam ketimpangan sosial dalam masyarakat, karena hal ini dapat merusak atau melemahkan perekonomian di tingkat daerah atau bahkan tingkat nasional dalam rangka pemberdayaan sumber daya manusia pada masyarakat pedesaan. Reformasi yang bergulir harus berpijak sesuai dengan penyelenggaraan dan berkesinambungan kerjasama yang baik antara pemerintahan daerah dengan Pemerintah Pusat. Reformasi otonomi daerah dalam pelaksanaan good governance, maka Pemerintah telah mengeluarkan Undang-undang Nomor 22 Tahun 1999 mengenai pemerintahan daerah, dan Undang-undang Nomor 25 Tahun1999 mengenai perimbangan keuangan antara pusat dan daerah, Seiring dengan berjalannya waktu di era pemerintahan saat itu, lahirlah Undang-undang Nomor 32 Tahun 2004 tentang pemerintahan daerah dan Undang-undang Nomor 33 Tahun 2004 mengenai Perimbangan Keuangan Pusat dan Daerah. Sebagai pengganti Undang-undang No. 22 Tahun 1999 dan No. 25 Tahun 1999 yang lebih menekankan pada reformasi manajemen sumber daya manusia dalam mewujudkan pemberdayaan sumber daya manusia pada masyarakat pedesaan yang lebih adil, merata, dan berdaya guna untuk pembangunan daerahnya.
\end{abstract}

Kata Kunci: Reformasi; Pemerintahan Daerah; Pemberdayaan Sumber Daya Manusia

\section{EFFECTIVENESS OF REGIONAL AUTONOMY IN BUILDING EMPOWERMENT OF HUMAN RESOURCES IN RURAL COMMUNITIES}

\begin{abstract}
The 1998 Reformation was the basis for revisiting the new regional autonomy system in realizing good governance, the essence of reforming the basis of a centralized society, nation and state, namely: (1) Amendment to the 1945 Constitution of the Republic of Indonesia ; (2) Government / State Administration bureaucratic reform, and (3) Reformation (building) Human Resources (rural communities). In realizing good governance so that it is in accordance with the fifth principle content of the Pancasila ideology and the Opening of the 1945 Constitution of the Republic of Indonesia, namely to educate the life of the nation and promote public welfare. In the process of implementing governance which is centralized there are still many kinds of social inequality in society, because this can damage or weaken the economy at the regional or even national level in the context of empowering human resources in rural communities. Revolving reforms must be based on the implementation and continuity of good cooperation between the regional government and the Central Government. In the framework of reforming regional autonomy in the implementation of good governance, the Government has issued Law No. 22 of 1999 concerning regional governance, and Law No. 25 of 1999 concerning financial balance between the center and the regions, along with the passage of time in the government era, Law No. 32 of 2004 concerning regional government and Law Number 33 of 2004 concerning Balance of Central and Regional Finance was born. In lieu of Law No. 22 of 1999 and No. 25 of 1999 which places more emphasis on reforming human resource management in realizing the empowerment of human resources in rural communities that are more just, equitable, and efficient for their regional development.
\end{abstract}

Key words: Reformation; Local government; Empowerment of Human Resources

\section{PENDAHULUAN}

Presiden B.J. Habibie mengeluarkan kebijakan otonomi daerah dengan tujuan untuk mengganti UU No. 5 Tahun 1974, ke arah yang lebih demokratis dan transparan. Habibie berpendapat bahwa untuk pembangunan/membangun sumber daya manusia jauh lebih penting atau bermanfaat dari pada mengeksplorasi potensi daerah, yaitu memberdayakan potensi manusia untuk mewujudkan pembangunan nasional yang berbasis pada kemajuan pembangunan daerah.

Kebijakan otonomi daerah harus memenuhi kriteria demokrasi dan pembangunan daerah yang riil dan transparan, oleh karena itu maka keluarlah UU No. 22/1999 dan UU No. 25/1999 dinilai sudah tidak relevan untuk tuntutan membangun sumber daya manusia, maka dengan seiring perjalan waktu dan proses pembangunan maka diganti oleh UU No. 32/2004, dan UU No. 33/2004 tentang perimbangan keuangan antara pemerintah pusat dan daerah, sebab hal ini agar dapat memiliki daya saing yang kuat terhadap era globalisasi saat ini, pada tahun 2005 saat itu mulai terjadi perubahan secara mendasar yang menjadikan pemerintahan daerah diberi kebebasan untuk mengurus sendiri roda pemerintahan dan pembangunan sebagai titik sentral dalam mendahulukan otonomi yang lebih luas, lebih nyata dan lebih bertanggungjawab tidak 
hanya pada bidang, sosial, ekonomi, politik, tetapi harus merata ke semua bidang, sehingga dapat meningkatkan akuntabilitas dan layanan publik.

Dengan demikian berbagai perubahan telah dilakukan dalam pelaksanaan Undang-undang No. 32 tahun 2004 dan Undang-undang No. 33 Tahun 2004 bertujuan meningkatkan akuntabulitas publik dan pelayanan publik, hal ini komponen system perbaikan secara berkelanjutan serta sesuai dengan asas demokrasi, khususnya menyangkut hubungan pemerintah pusat dan daerah, dalam mewujudkan pembangunan daerahnya harus sesuai dengan ketentuan undang-undang yang telah dibuat, sehingga sejalan dengan tujuan pemberian otonomi daerah, yaitu: 1. meningkatan pelayanan publik (public service) secara profesional, efektif dan efisien; 2. mengembangkan kehidupan berdemokrasi; 3 . berkeadilan; 4. pemerataan pembangunan setiap wilayah daerah; 5. lebih dipeliharanya komunikasi yang serasi 6 . lebih berpihak pada pemberdayaan terhadap masyarakat, dan 7. membangun kepercayaan diri dan kreativitas untuk meningkatkan peran serta masyarakat, dan untuk lebih berperan aktif dan memberdayakan dewan perwakilan rakyat daerah

Masalah kepemimpinan birokrasi dan membangun budaya kepemimpinan profesional birokrasi di Indonesia sangat berpengaruh kepada efektivitas otonomi daerah dalam membangun pemberdayaan sumber daya manusia. Dalam banyak tulisan telah dikemukakan mengenai bagaimana mengembangkan budaya profesionalme kepemimpinan, kemudian banyak diatur dalam berbagai macam literarur manajemen bahwa kepemimpinan pegang peranan penting dalam mendukung suatu keberhasilan untuk pencapaian tujuan organisasi, dalam berorganisasi apapun jenis organisasinya pasti memiliki dan memerlukan seorang pemimpin (leader, pimpinan puncak/top manager) yang harus siap bertanggungjawab dalam menjalankan kegiatan bagi organisasi sebagai suatu kesatuan, lebih jauh dikemukakan (Owens 1995) kepemimpinan di sini merupakan suatu bentuk interaksi yang dijalankan dengan profesional, efektif dan efisien antara pemimpin dan yang dipimpin.

Pemimpin yang baik dapat melihat dan memberikan apresiasi terhadap bawahannya dengan cara menghargai bawahannya atas dasar mengembangkan kemampuan diri mereka dalam pencapaian visi yang telah dirumuskan guna mewujudkan tujuan organisasi. Agar dapat memotivasi bawahannya seorang pemimpin dapat memberikan beberapa hal yang dapat memacu semangat bawahan yaitu sebagai berikut:

1. lebih meyakinkan peran bawahannya bahwa suatu visi organisasi penting untuk dicapai;

2. memotivasi atau memberikan suatu tantangan kepada bawahan dengan tujuan agar semua tanggungjawab dan kewajiban dalam melaksanakan pekerjaan dapat lebih cermat dan teliti dan hal ini juga harus memperhitungkan perasaan diri bawahan yang dipimpin akan tingkat kesuksesan atas prestasi kinerja, dan kecakapan dalam bekerja.

3. Memberikan reward (penghargaan) yang layak kepada bawahan yang memiliki kinerja baik dengan memberikan reward (penghargaan), baik berupa bonus atau bahkan memberikan promosi.

Ada suatu pepatah Jawa yaitu "Jer basuki mawa bae": ini merupakan suatu pepatah yang sangat populer dan akrab dalam masyarakat kita, yang menunjukan pada efek konsekuensi finansial atas perolehan prestasi kinerja. Saat ini, pendidikan yang berkualitas tinggi sering diidentikkan dengan mahalnya biaya. Banyak kalangan bahkan sebagian masyarakat dan stakeholders memandang bahwa gejala pembiaran pada kapitalisasi sekolah telah merebak dan merusak tujuan tatanan pendidikan itu sendiri, sehingga mengakibatkan pendidikan yang semula diharapkan mampu untuk membangun potensi diri dan derajat hidup masyarakat miskin untuk meraih keberhasilan di masa akan datang, hal ini menunjukan semakin menjauh terhadap harapan dan kenyataan yang diperolehnya. Sungguh ironis dan bertolak belakang dari pendapat ahli pendidikan bahwa dunia pendidikan saat ini cara untuk menurunkan garis kemiskinan dan kebodohan, justru malah semakin menghambat bagi perubahan masyarakat miskin di negeri ini dalam menurunkan jumlah garis kemiskinan. Semua kejadian dan keadaan ini terus berlangsung hingga saat kini karena disebabkan oleh kurangnya atau minimnya keberpihakan pemerintah kepada dunia pendidikan nasional, kurangnya ketersediaan sarana dan prasarana untuk jalan masuk yang lebih besar kepada golongan masyarakat yang tidak mampu sehingga terjangkau untuk mendapatkan jenjang pendidikan lebih tinggi yang relatif murah tapi berkualitas dan berkarakter.

Mengingat pada keinginan bangsa Indonesia yang tercantum dalam Mukadimah UUD 1945 adalah mencerdaskan kehidupan bangsa yang diimplementasikan melalui UU Sistem Pendidikan Nasional No. 20/2003 mengenai berbagai macam diantaranya "Pengembangan potensi peserta didik supaya menjadi insan kamil yang beriman dan bertaqwa akhlakul karimah, sehat jasmani dan rohani, berilmu pengetahuan, terampil, kreatif dan inovatif, berdikari, dan sebagai warganegara yang bermasyarakat, berbangsa dan bernegara dengan baik dan taat aturan ". (Abdul Wahid, 2011: 105).

Para ahli pendidikan telah sepakat bahwa membangun manajemen sumber daya manusia harus melalui proses pembelajaran dan pendidikan yang dilakukan di sekolah. Menurut Sinaga (2016:219). Peningkatan dan pengembangan manajemen potensi manusia bisa didapat melalui proses belajar dan mengajar secara terus menerus melalui badan penyelenggara pendidikan, baik secara formal maupun informal dengan berbagai bentuk macam pendidikan dan pelatihan sesuai bakat dan kemampuan. 
Manusia harus bersosialisasi dengan manusia lainnya, misal, proses pembelajaran melibatkan guru dan peserta didik sebagai faktor manusianya, adapun tugas dari pendidik itu sendiri adalah berusaha untuk mencerdaskan dan membangun karakter peserta didiknya, membangun dan mengembangkan pengetahuan atau menjauhi kebodohan. Menurut UU No. 20 Tahun 2003 Pasal 30 membahas mengenai pengembangan potensi kemampuan, membentuk potensi yang berkarakter, serta peradaban bangsa yang berharkat dan bermartabat untuk mewujudkan cita-cita bangsa Indonesia.

Menghadapi era kompetitif sekarang ini setiap negara mulai mengarahkan kepada masyarakatnya mulai menuntut atau mengarahkan setiap orang tidak harus cerdas saja, akan tetapi juga harus memiliki kreativitas, inisiatif, dan inovatif untuk menggagas dan menemukan pemikiran-pemikiran baru yang terbarukan, melakukan riset dan pengembangan teknologi modern yang berkualitas yang memiliki daya saing dengan negara-negara maju, untuk pencapaian hal tersebut diperlukan suatu pola pikir dan sikap, serta perilaku kreatif yang dibangun dan dikembangkan sejak usia dini agar siswa kelak nantinya menjadi pencipta dan pencetus gagasan pengetahuan baru, yang memiliki kompetensi untuk menciptakan lapangan kerja baru (wiraswasta) yang luas. Telah dijelaskan pengembangan potensi kreativitas dalam sistem pendidikan nasional. Undang-undang Sistem Pendidikan Nasional (Sisdiknas) No. 20 Tahun 2003 Bab III pada Pasal 4 menekankan bahwa: "Pendidikan diselenggarakan dengan memberi keteladanan membangun kemauan, dan mengembangkan kreativitas peserta didik dalam proses pembelajaran". (Solihat, 2010).

Begitu pula dengan efektivitas otonomi daerah dalam membangun pemberdayaan sumber daya manusia pada masyarakat pedesaan harus dilandasi oleh pendidikan yang efektif dan kuat agar melahirkan peserta didik yang memiliki kepemimpinan yang bertanggungjawab, dinamis, dan inovatif guna mencapai tujuan-tujuan otonomi daerah.

\section{METODE}

Penulis melakukan penelitian ini menggunakan metode penelitian deskriptif kualitatif yang bersifat mendeskripsikan tentang masalah yang akan diteliti kemudian ditelaah, dikaji, dan dianalisis berdasarkan teori. Penelitian deskriptif memberikan suatu gambaran yang terinci mengenai hal satu situasi khusus, tatanan sosial, atau hubungan yang terkait dengan hal-hal yang akan dikemukakan. Seringkali temuan penelitian sosial dalam jurnal digunakan untuk membuat putusan kebijakan adalah deskriptif (Neuman, 2000).

Adapun untuk memperoleh data yang updated dan akurat atau informasi yang dibutuhkan, penulis menggunakan teknik pengumpulan data sebagai berikut: Penelitian Kepustakaan (library research), merupakan metode penelusuran terhadap sumber-sumber tertulis atau deskriptif tentang suatu pemikiran atau fenomena (Hadi, 1995:5). Metode ini penulis gunakan untuk menggali pemikiran yang terdapat dalam buku primer maupun sekunder yaitu dengan cara mengumpulkan dan menelaah, mengkaji serta menganalisis data kepustakaan dari berbagai literatur seperti buku, website atau internet, makalah, jurnal, artikel, dan laporan dokumen-dokumen penelitian sosial yang terbaru serta sarana informasi lainnya yang berhubungan dengan masalah-masalah dalam penelitian ini.

\section{HASIL DAN PEMBAHASAN}

Tuntutan perluasan otonomi daerah di Indonesia makin meluas dan hal ini merupakan hak, wewenang, dan kewajiban daerah otonom untuk mengatur dan mengurus sendiri urusan pemerintahan dan kepentingan masyarakat luas yang ada di daerah setempat atau pedesaan sejalan dan sesuai dengan peraturan perundang-undangan. Menurut Suparmoko (2006:61) otonomi daerah sebagai kewenangan daerah otonom untuk mengatur dan mengurus kepentingan masyarakat setempat menurut prakarsa sendiri berdasarkan aspirasi masyarakat.

Berkenaan dengan pelaksanaan desentraslisasi otonomi daerah di Indonesia terdapat dua nilai dasar sebagai mana diamanatkan dalam UUD Republik Indonesia Tahun 1945 Pasal 18 ayat (2) yaitu:

1. Nilai Unitaris yang diwujudkan dalam pemikiran bahwa Indonesia tidak mempunyai kesatuan pemerintahan lain di dalamnya yang bersifat negara ("Eenheidstaat"), hanya satu yaitu sebagai Negara Kesatuan Republik Indonesia;

2. Sebagaimana telah dijelaskan di atas maka jelaslah bahwa Pemerintah diwajibkan untuk melaksanakan politik desentralisasi dan dekonsentrasi di bidang ketatanegaraan yang lebih berperikemanusiaan dan berperikeadilan.

Untuk diketahui juga bahwa awalnya diberlakukan Undang-undang tentang otonomi daerah yang berdasarkan kebijakan otonomi daerah, adalah sebagai berikut:

1. Peraturan perundang-undangan tentang otonomi daerah di Indonesia yang pertama mengatur terhadap arah dan tujuan wewenang agar pelaksanaan daerah otonom di provinsi, kota, kabupaten memiliki tujuan yang sama yakni dalam menetapkan dan mewujudkan kemakmuran masyarakat daerah dan nasional.

2. undang-undang Nomor 32/2004 juga mengatur tentang pemerintahan daerah. Dalam kebijakan ini secara komprehensif membahas mengenai pemerintah daerah otonom sebagai penyelenggaraan otonomi daerah di Indonesia. Dengan diberlakukannya Undang-undang tersebut dapat dengan mudah mempertimbangkan dan memutuskan suatu kebijakan pendukung yang lebih ringkas sehingga lebih efektif dalam menyelenggarakan pemerintahan daerah. 
Secara umum otonomi diartikan sebagai "mandiri”, sedangkan dalam arti yang lebih menekankan pada otonomi daerah yaitu "memberdayakan". Jadi yang dimaksud daerah otonom di sini adalah memberikan otoritas agar berdikari sesuai dengan kebijakan atau keputusan mengenai pembangunan daerah setempat.

Krisis multikrisis yang terjadi pada 1997 dalam kehidupan politik berdampak pada tatanan ekonomi masyarakat di negeri ini yang dibangun sudah puluhan tahun lamanya. hal itu menyebabkan untuk mengelola dan mengatur potensi daerahnya masing-masing menjadi kesulitan. Para intelektual Muslim menyatakan bahwa otonomi daerah ini sesuai keinginan bersama, yang disebut dengan masyarakat madani yang dibangun dengan nilai-nilai akhlak dan moral.

Para pendiri republik sudah memberikan suatu dasar pijakan yang kuat kepada bangsa dan negara Indonesia untuk membangun masyarakat madani yang berfalsafah Pancasila dan UUD 1945. Sebagai tanggapan atau respon terhadap multikrisis tersebut, pada masa reformasi disosialisasikan dalam suatu kebijakan yang terstruktur secara sistematis terhadap pemerintah yang bijaksana dan adil, yaitu dengan penerapan otonomi daerah, hakikatnya adalah suatu bentuk pelaksanaan untuk mewujudkan pemerintahan yang baik (good governance), untuk mengefektifkan otonomi daerah dalam rangka membangun pemberdayaan sumber daya manusia pada masyarakat pedesaan sehingga memberikan makna bahwa dalam mewujudkan efektivitas otonomi daerah dalam membangun pemberdayaan sumber daya manusia pada masyarakat pedesaan, intinya adalah melalui pelayanan publik. Sarana pendidikan merupakan salah satu bentuk pelayanan publik kepada masyarakat agar masyarakat pedesaan menjadi berkemampuan untuk "mandiri" atau "berdaya".

Membangun pemberdayaan sumber daya manusia, kuncinya ada pada diri manusia. Karena, membangun manajemen sumber daya manusia itu harus melalui proses pembelajaran dan pendidikan yang melibatkan guru dan peserta didik sebagai sumber daya manusia. Menurut Dahlan dan Sumaryana (2017:46-47), salah satu tata kelola pemerintahan yang akuntabel, dan bersih harus bisa memberikan pelayanan yang terbaik ini sebagai tanda terwujudnya Good Governance. Dalam pelaksanaan good governance dapat terwujud dengan adanya kerjasama yang baik sesuai dengan kemampuan pemerintah, masyarakat madani, dan kebutuhan publik.

Pelayanan publik yang menekankan pada proses pembelajaran dan pendidikan kepada masyarakat pedesaan harus mampu memanfaatkan kemajuan teknologi komunikasi dan informasi, tatanan sosial-politik masyarakat, dan perundang-undangan hasil lembaga legislatif masih jauh dari pembangunan masyarakat yang adil merata. Untuk terwujudnya pelayanan publik yang baik dan bersih, maka yang harus diperhatikan adalah terselenggaranya otonomi daerah profesional, efektif dan efisien, yang dapat dilakukan melalui pengembangan sistem manajemen pemerintahan yang efektif, obyektif, rasional, modern, dan berperadaban.

Perkembangan teknologi informasi terus berkembang dengan pesat. Jika pemerintahan daerah dengan wewenang otonomi daerah yang dilimpahkan oleh Pemerintah Pusat kepada Daerah, harus memperhatikan, mengikuti, dan memanfaatkan perkembangan teknologi informasi tersebut untuk membangun pemberdayaan sumber daya manusia pada masyarakat pedesaan yang adil dan merata. Menurut Buchari (2016:225) perkembangan teknologi dan infromasi yang berkembang semakin hari semakin canggih atau modern, mau tidak mau pemerintah harus mengikuti dan mengikuti perkembangan teknologi dan informasi, kebutuhan teknologi dan informasi sudah berkembang dan berakar didalam masyarakat saat ini, di mana teknologi dan informasi menjadi keharusan yang mendasar dari kebutuhan bagi pelayanan publik sehingga dalam pelayanan terhadap publik di rasakan dan didapatkan secara efektif dan efisien, hal ini seiring dengan yang di inginkan oleh masyarakat menjadi pemerintah yang dinamis dengan memperhatikan dan disesuaikan dengan perkembangan teknologi modern. Oleh karenanya pelayanan publik dengan menggunakan teknologi informasi dapat dimanfaatkan oleh pemerintah dalam mewujudkan persyaratan sebagai good governance, sehingga didapat peningkatkan secara akuntabilitas, transparansi, efektif dan efisien.

\section{SIMPULAN}

Pada tulisan artikel ini penulis dapat menarik suatu simpulan bahwa kepemimpinan adalah merupakan suatu kemampuan dari seseorang untuk mempengaruhi pikiran dan perilaku agar orang-orang/individu mau dengan ikhlas bekerja untuk mencapai tujuan-tujuan organisasi. Efektivitas otonomi daerah dalam membangun pemberdayaan sumber daya manusia pada masyarakat pedesaan perlu pemimpin yang memiliki kepemimpinan (leadership) yang cerdas, dinamis, inovatif, dan bertanggung-jawab kepada dirinya sendiri maupun kepada masyarakat (orang-orang) yang dibawah kepemimpinannya. Pemimpin yang cerdas adalah pemimpin yang amanah.

Dengan demikian, maka efektivitas otonomi daerah dalam membangun pemberdayaan sumber daya manusia pada masyarakat pedesaan, intinya terletak pada diri manusia itu sendiri, identik dengan kunci pendidikan itu terletak pada manusianya.

\section{DAFTAR PUSTAKA}

Buchari, R.A. (2016). Implementasi E-Service Pada Organisasi Publik di Bidang Pelayanan Publik Di Kelurahan Cibangkong Kecamatan Batununggal Kota Bandung. Sosiohumaniora, 18, (3), 235-239. 
Collins, J. (2001). Good to Great: Why Some Companies Make the Leap and Others Don't?, Harper Collins Publication, New York.

Dahlan, M \& Sumaryana, A. (2017). Pengaruh Penerapan Good Governance Terhadap Kinerja Pelayanan Publik, Budaya Organisasi Dan Lingkungan Eksternal Sebagai Pemoderasi. Sosiohumaniora, 19, (1), 45-51.

https://id.wikipedia.org/wiki/Otonomi_daerah_di Indonesia. Diakses pada 02 Oktober 2018 pukul 12.30 wib.

https://guruppkn.com/peraturan-perundang-undanganotonomi-daerah. Diakses pada 02 Oktober 2018 pukul 12.54 wib.

Sinaga, D. (2016). Hubungan Sumber Daya Manusia dan Sosial Budaya dengan Tingkat Kesejahteraan Masyarakat Di Kecamatan Senembah Tanjung Muda Hulu Kabupaten Deli Serdang, Sosiohumaniora, 18, (3) 218 - 226
Wahid, A. (2011) Isu-Isu Kontemporer Pendidikan Islam, Semarang : Walisongo Press, Cetakan I.

Suparmoko, M. (2002). Ekonomi Publik, Untuk Keuangan dan Pembangunan Daerah. Andi. Yogyakarta

Owens, Robert G. Organizational Behaviour in Education, (Boston: Allyn and Bacon, 1995).

Neuman, W.L. (2000). Social Reseach Methods: Qualitative and Quantitative Approaches, Boston: $4^{\text {th }}$ Edition, Allyn \& Bacon.

Hadi, S. (1995). Metodologi Reseach, Yogyakarta: Yayasan Penerbitan Fakultas Psikologi UGM, hal. 5

Solihat, E. (2010). Pengaruh Pendekatan Open-ended Terhadap Kemampuan Berpikir Kreatif Siswa dalam Belajar Matematika. (Penelitian Quasi Eksperimen di MTsN Model Babakan Sirna). Jakarta: Skripsi, Jurusan Pendidikan Matematika, Fakultas Ilmu Tarbiyah dan Keguruan, Universitas Islam Negeri (UIN) Syarif Hidayatullah. 